\title{
Effect of Mixed Industrial Effluent on the Growth of Abelmoschus Esculentus
}

\begin{abstract}
Sajid Ali ${ }^{1}$, Masood Alam ${ }^{2}$
Firoz Ali Ansari, Tabassum Akhtar

Environmental Science Laboratory, Department of Applied Sciences \& Humanities, Faculty of Engineering \& technology, Jamia Millia Islamia, New Delhi, India

Abstract: The present study has been carried out to see the effect of mixed industrial effluent collected from Okhla Industrial Area phase-II, New Delhi-110025, India on seed germination and growth of the Okra (Abelmoschus esculentus). The Okra seeds were placed on the petri-dishes lined with cotton and covered with filter paper for seed germination and earthen pots were used for recording the plant growth after treating with different concentration of effluents viz controlled (0\%), $25 \%, 75 \%, 100 \%$. Germination percentage of seeds was recorded highest at $25 \%$ concentration of effluent. The plant growth also recorded highest at $25 \%$ concentration of the effluent. The study reveals that the germination of seeds and growth of the plants gradually declined with the increasing concentration of the effluent. The study suggests that the effluent may be used for agricultural purposes if proper dilution is taken up.
\end{abstract}

Keywords: Effluent; Pollutant; Seed germination; Abelmoschus esculentus; Effluent Tolerance Index (ETI).

\section{Introduction}

Industrialization play an important role in the development process but the wastewater disposal has become a global dilemma for the industries because of generation of high volume of effluents, limited space for land based treatment $\&$ disposal and high cost of treatment technologies (Kumar \& Chopra). Normally wastewater is used for irrigation purposes in many countries which are suffering from low availability of water (Al-Ansari et. al. 2013., Arora et. al. 2008). Pollution is a matter of great concern because of its adverse effects on human health, animals, plants and various exposed materials (Nawaz et. al. 2006). Effluents affect the time of flowering and fruiting number of fruits, weight of fruits and effect on vascular bundles (Uaboi-Egbenni et. al. 2009). The utilization of industrial effluents for irrigation of crop plants is a highly beneficial solution to control the pollution (Medhi et. al. 2008). Industrial waste contains very poisonous salts, alkalis, acids, odour, gases, heavy metals, insecticides etc. These polluted wastes are thrown into the canals, streams or rivers affecting the quality of water, making the water unfit for irrigation purposes and for other uses (Malik et. al. 2003). Seed germination is a fascinating process. The industrial effluents possess various organic and inorganic chemical compounds. The presence of these chemicals will show detrimental effects on the development of plant, germination process and growth of seedlings (Wins and Murugam. 2010, Vijaakumari and Kumudha. 1990, Vijayarengan and
Lakshyamanachary. 1993). Treated industrial effluents can be used for irrigation purposes but when the effluent is used without any treatment, toxic substances present in the effluent reduces crop growth and gives severe adverse effect on soil properties (Medhi et. al. 2008). Effluent released with high temperature can raise the temperature of water bodies, reducing the solubility of oxygen in the water and increasing the $\mathrm{pH}$ value of the receiving body (Ara begum et. al. 2010, Rao et. al. 1983).

\section{Materials and Method}

In the present study attempts have been made to investigate pollutants of wastewater effluents of Okhla Industrial Area Phase-II, New Delhi and their effects on seed germination and plant growth of Abelmoschus esculentus. The present study was conducted with five different concentrations of effluent collected from industrial area phase-II New Delhi situated at 28.53 latitude and 77.25 Longitude. The physico-chemical properties of the effluent were analyzed by the procedure of APHA (1992) in the Environmental Science Laboratory, Department of Applied Sciences and Humanities, Faculty of Engineering and Technology, Jamia Millia Islamia, New Delhi, India since 28 August 2014 to 28 October 2014. The sets were made by dissolving calculated amount of effluents in tap water i.e. $\mathrm{T}_{\mathrm{c}}, \mathrm{T}_{25}, \mathrm{~T}_{50}, \mathrm{~T}_{75}, \mathrm{~T}_{100}$ and by maintaining the ratio of effluent and tap water as-0:100, 25:75, 50:50, 75:25, 100:0 respectively as shows in table -01 .

Table 1: Different dilution levels of industrial effluent with different ratios

\begin{tabular}{|c|c|c|c|c|c|}
\hline S.N & $\begin{array}{c}\text { Volume of effluent } \\
(\%)\end{array}$ & $\begin{array}{c}\text { Volume of tap water } \\
(\%)\end{array}$ & $\begin{array}{c}\text { Concentration (V/V) } \\
\text { Effluent }: \text { Water }\end{array}$ & $\begin{array}{c}\text { Final concentration } \\
(\%)\end{array}$ & Symbol \\
\hline 1. & 0 & 100 & $0: 100$ & 0 & $\mathrm{~T}_{c}$ \\
\hline 2. & 25 & 75 & $25: 75$ & 25 & $\mathrm{~T}_{25}$ \\
\hline 3. & 50 & 50 & $50: 50$ & 50 & $\mathrm{~T}_{50}$ \\
\hline 4. & 75 & 25 & $75: 25$ & 75 & $\mathrm{~T}_{75}$ \\
\hline 5. & 100 & 0 & $100: 0$ & 100 & $\mathrm{~T}_{100}$ \\
\hline
\end{tabular}




\section{International Journal of Science and Research (IJSR) \\ ISSN (Online): 2319-7064 \\ Index Copernicus Value (2013): 6.14 | Impact Factor (2014): 5.611}

Industrial effluent of different concentrations was used to investigate the effect of effluent on seed germination and yearly growth of Abelmoschus esculentus (variety name Arka Anamika) which was bought from Indian Agriculture research Institute (IARI), PUSA, New Delhi. During experiment thirty seeds of Abelmoschus esculentus were collected and sterilized by $0.1 \%$ of mercuric chloride solution which helped to remove the microbes. The seed were then spread on the Petri dishes lined with cotton and covered with filter paper. The seeds were then irrigated with equal Volumes $(20 \mathrm{ml})$ of different concentration of each set of three replicates at certain time interval. The germinated seeds were taken out from petri-dishes when there was no further germination. Pot culture experiment was carried out to study the effect of industrial effluent on the growth of Abelmoschus esculentus. Earthen pots were filled with air dry soil. The collected effluent was considered as 100 percent concentration. Different dilutions of effluent viz 0, 25, 50 75 percent were prepared from 100 percent concentration of effluent by adding tap water. Earthen pots filled with dry soil were prepared for separate treatment with Neem and cow dung. Three replications were maintained for each level of concentration of effluent. One set of earthen pot was arranged without applying any effluent (as control). Tap water was used in control. The pots were irrigated with respective concentrations of effluent and kept for 60 days. After a gap of 15, 30, 45 and 60 days, the root length, shoot length, fresh weight and dry weight were recorded.

Germination Percentage: Germination percentage of seed refers to the initial appearance of the radicle. It was calculated by using the following formula (Mahalingum et. al.2014).

Germination percentage $=$ Number of seed germpiolbatand present in the effluent. The results for root length Total number of seed Aphem ${ }_{\text {With }}$ different effluent concentrations are shows in table- 4 .

Effluent Tolerance Index (ETI): The effluent tolerance

index was calculated using the formula determined by

Turner \& Marshal. 1972, Bhale. et. al. 2011.

ETI $=\frac{\text { Mean length of root \& shoot in effluent }}{\text { Mean length of the largest root \& shoot in the control }}$

\section{Results and Discussion}

The physicochemical characteristics of the collected effluent are presented in Table-2.

Table 2: Physico-Chemical characteristics of the effluents

\begin{tabular}{|c|c|c|}
\hline$S . N$ & Parameters & Value \\
\hline 1. & Colour & Brownish \\
\hline 2. & Temperature $($ Celsius $)$ & 33 \\
\hline 3. & $\mathrm{pH}$ & 7.93 \\
\hline 4. & $\mathrm{EC}(\mu \mathrm{S})$ & 1.68 \\
\hline 5. & TDS $(\mathrm{mg} / \mathrm{l})$ & 620 \\
\hline 6. & BOD $(\mathrm{mg} / \mathrm{l})$ & 288 \\
\hline 7. & COD $(\mathrm{mg} / \mathrm{l})$ & 408 \\
\hline 8. & Alkalinity $(\mathrm{mg} / \mathrm{l})$ & 48.8 \\
\hline 9. & Chloride $(\mathrm{mg} / \mathrm{l})$ & 2613.73 \\
\hline 10. & Sulphate $(\mathrm{mg} / \mathrm{l})$ & 68 \\
\hline
\end{tabular}




\section{International Journal of Science and Research (IJSR) ISSN (Online): 2319-7064 \\ Index Copernicus Value (2013): 6.14 | Impact Factor (2014): 5.611}

Table 4: Root Length (mm/plant) of Abelmoschus esculentus grown under different concentrations with different soil treatments. $(n=3$. Mean \pm SD $)$

\begin{tabular}{|c|c|c|c|c|c|}
\hline \multirow{2}{*}{ Soil Treatment } & \multirow{2}{*}{$\begin{array}{c}\text { Effluents } \\
\text { concentration }\end{array}$} & \multicolumn{4}{|c|}{ Age of the plants (days after sowing) } \\
\hline & & 15 & 30 & 45 & 60 \\
\hline \multirow{5}{*}{$\begin{array}{l}\text { Soil without } \\
\text { treatment }\end{array}$} & $0 \%$ & $52.6 \pm 7.522$ & $77.6 \pm 5.131$ & $93.3 \pm 7.505$ & $100.0 \pm 3.464$ \\
\hline & $25 \%$ & $72.1 \pm 10.774$ & $98.3 \pm 3.21$ & $97.0 \pm 6.557$ & $92.3 \pm 3.214$ \\
\hline & $50 \%$ & $78.6 \pm 5.392$ & $82.3 \pm 3.511$ & $84.6 \pm 5.131$ & $88.0 \pm 1.802$ \\
\hline & $75 \%$ & $68.0 \pm 3.122$ & $71.6 \pm 11.846$ & $82.6 \pm 4.725$ & $87.1 \pm 4.163$ \\
\hline & $100 \%$ & $51.6 \pm 8.129$ & $63.3 \pm 19.139$ & $75.0 \pm 14.177$ & $87.0 \pm 2.783$ \\
\hline \multirow{5}{*}{$\begin{array}{l}\text { Soil with cow } \\
\text { dung treatment }\end{array}$} & $0 \%$ & $52.5 \pm 7.365$ & $77.6 \pm 4.932$ & $93.8 \pm 5.619$ & $93.5 \pm 8.231$ \\
\hline & $25 \%$ & $65.0 \pm 19.467$ & $95.6 \pm 4.932$ & $97.8 \pm 5.204$ & $98.1 \pm 6.291$ \\
\hline & $50 \%$ & $61.3 \pm 12.223$ & $82.3 \pm 3.214$ & $86.1 \pm 4.509$ & $87.8 \pm 1.755$ \\
\hline & $75 \%$ & $60.5 \pm 8.261$ & $81.6 \pm 4.041$ & $86.1 \pm 6.350$ & $95.6 \pm 3.329$ \\
\hline & $100 \%$ & $59.6 \pm 1.040$ & $70.0 \pm 11.532$ & $86.6 \pm 9.865$ & $90.3 \pm 0.288$ \\
\hline \multirow{5}{*}{$\begin{array}{l}\text { Soil with Neem } \\
\text { treatment }\end{array}$} & $0 \%$ & $56.3 \pm 8.504$ & $82.3 \pm 3.511$ & $97.0 \pm 5.291$ & $107.3 \pm 7.234$ \\
\hline & $25 \%$ & $73.8 \pm 13.613$ & $147.3 \pm 41.860$ & $98.0 \pm 12.165$ & $110.1 \pm 6.448$ \\
\hline & $50 \%$ & $79.5 \pm 1.322$ & $89.6 \pm 11.015$ & $86.3 \pm 3.785$ & $99.6 \pm 2.843$ \\
\hline & $75 \%$ & $60.6 \pm 17.243$ & $72.0 \pm 4.000$ & $85.3 \pm 7.751$ & $98.0 \pm 3.968$ \\
\hline & $100 \%$ & $60.6 \pm 1.527$ & $65.6 \pm 10.408$ & $85.6 \pm 3.818$ & $95.3 \pm 15.50$ \\
\hline
\end{tabular}

The root length in soil without treatment was recorded the highest at 50 percent concentration for 15 days while the root lengths were recorded as highest with 25 percent concentration for 30,45 and 60 days.
The highest root length in soil with cow dung treatment and Neem treatment were recorded at 25 percent effluent concentration for 15, 30, 45 and 60 days. The results for shoot length of Abelmoschus esculentus with different sets of soil and effluent concentration are shown in table5 .

Table 5: Shoot Length (mm/plant) of Abelmoschus esculentus grown under different concentrations of effluent with different soil treatments. $(n=3$. Mean $\pm S D)$.

\begin{tabular}{|c|c|c|c|c|c|}
\hline Soil Treatment & \multirow{2}{*}{$\begin{array}{c}\text { Effluents } \\
\text { concentration }\end{array}$} & \multicolumn{4}{|c|}{ Age of the plants (days after sowing) } \\
\hline \multirow{6}{*}{$\begin{array}{l}\text { Soil without } \\
\text { treatment }\end{array}$} & & 15 & 30 & 45 & 60 \\
\hline & $0 \%$ & $45.0 \pm 4.769$ & $61.6 \pm 7.637$ & $107.0 \pm 9.165$ & $119.6 \pm 23.115$ \\
\hline & $25 \%$ & $67.3 \pm 4.618$ & $85.3 \pm 17.616$ & $105.3 \pm 9.504$ & $138.3 \pm 8.326$ \\
\hline & $50 \%$ & $64.6 \pm 8.550$ & $79.3 \pm 11.676$ & $99.3 \pm 1.527$ & $118.3 \pm 14.511$ \\
\hline & $75 \%$ & $63.3 \pm 9.814$ & $58.6 \pm 11.930$ & $86.0 \pm 18.734$ & $126.6 \pm 13.768$ \\
\hline & $100 \%$ & $52.3 \pm 10.016$ & $48.0 \pm 28.213$ & $93.0 \pm 4.358$ & $111.5 \pm 12.031$ \\
\hline \multirow{5}{*}{$\begin{array}{l}\text { Soil with cow } \\
\text { dung } \\
\text { treatment }\end{array}$} & $0 \%$ & $48.0 \pm 6.726$ & $57.0 \pm 4.358$ & $114.3 \pm 15.332$ & $118.3 \pm 5.346$ \\
\hline & $25 \%$ & $70.6 \pm 1.258$ & $79.0 \pm 16.822$ & $111.1 \pm 10.598$ & $144.3 \pm 16.041$ \\
\hline & $50 \%$ & $58.8 \pm 2.466$ & $73.3 \pm 2.309$ & $97.0 \pm 4.444$ & $142.3 \pm 42.253$ \\
\hline & $75 \%$ & $45.0 \pm 15.716$ & $60.6 \pm 7.023$ & $101.6 \pm 9.385$ & $138.3 \pm 21.097$ \\
\hline & $100 \%$ & $52.0 \pm 2.000$ & $56.6 \pm 4.163$ & $94.5 \pm 5.220$ & $140.6 \pm 21.031$ \\
\hline \multirow{5}{*}{$\begin{array}{l}\text { Soil with } \\
\text { Neem } \\
\text { Treatment }\end{array}$} & $0 \%$ & $50.1 \pm 2.020$ & $73.6 \pm 7.767$ & $114.0 \pm 16.093$ & $134.8 \pm 49.614$ \\
\hline & $25 \%$ & $74.1 \pm 2.020$ & $102.6 \pm 11.846$ & $120.0 \pm 1.500$ & $174.8 \pm 14.631$ \\
\hline & $50 \%$ & $69.5 \pm 9.987$ & $101.0 \pm 19.284$ & $101.0 \pm 1.322$ & $154.8 \pm 21.426$ \\
\hline & $75 \%$ & $63.5 \pm 6.062$ & $78.6 \pm 6.429$ & $99.8 \pm 2.020$ & $156.0 \pm 13.500$ \\
\hline & $100 \%$ & $57.6 \pm 2.843$ & $75.6 \pm 8.962$ & $96.0 \pm 4.924$ & $137.6 \pm 33.126$ \\
\hline
\end{tabular}

The shoot lengths of the Abelmoschus esculentus were recorded as highest in all sets of soil at 25 percent effluent concentration for all 15, 30, 45 and 60 days except for the soil without treatment and the soil with cow dung treatment which showed the reduction in shoot length. The Effluent tolerance index (ETI) values for root and shoot are shown in table-6. 


\section{International Journal of Science and Research (IJSR) \\ ISSN (Online): 2319-7064}

Index Copernicus Value (2013): 6.14 | Impact Factor (2014): 5.611

Table 6: Effluent Tolerance Index (ETI)

\begin{tabular}{|c|c|c|c|c|c|c|}
\hline \multirow{2}{*}{ Soil Treatment } & \multirow{2}{*}{$\begin{array}{c}\text { Effluent } \\
\text { concentration }\end{array}$} & & \multicolumn{4}{|c|}{ Age of the plants (days after sowing) } \\
\hline & & & 15 & 30 & 45 & 60 \\
\hline \multirow{8}{*}{$\begin{array}{l}\text { Soil without } \\
\text { treatment }\end{array}$} & \multirow[t]{2}{*}{$25 \%$} & Root & 1.37 & 1.26 & 1.03 & 0.92 \\
\hline & & Shoot & 1.49 & 1.38 & 0.98 & 1.15 \\
\hline & \multirow[t]{2}{*}{$50 \%$} & Root & 1.49 & 1.06 & 0.90 & 0.88 \\
\hline & & Shoot & 1.43 & 1.28 & 0.92 & 0.98 \\
\hline & \multirow[t]{2}{*}{$75 \%$} & Root & 1.29 & 0.92 & 0.88 & 0.87 \\
\hline & & Shoot & 1.40 & 0.95 & 0.80 & 1.05 \\
\hline & \multirow[t]{2}{*}{$100 \%$} & Root & 0.98 & 0.81 & 0.80 & 0.87 \\
\hline & & Shoot & 1.16 & 0.77 & 0.86 & 0.93 \\
\hline \multirow{8}{*}{$\begin{array}{l}\text { Soil with cow } \\
\text { dung treatment }\end{array}$} & \multirow[t]{2}{*}{$25 \%$} & Root & 1.23 & 1.23 & 1.04 & 1.04 \\
\hline & & Shoot & 1.47 & 1.38 & 0.97 & 1.21 \\
\hline & \multirow[t]{2}{*}{$50 \%$} & Root & 1.16 & 1.06 & 0.91 & 0.93 \\
\hline & & Shoot & 1.22 & 1.28 & 0.84 & 1.20 \\
\hline & \multirow[t]{2}{*}{$75 \%$} & Root & 1.15 & 1.05 & 0.91 & 1.02 \\
\hline & & Shoot & 0.93 & 1.06 & 0.88 & 1.16 \\
\hline & \multirow{2}{*}{$100 \%$} & Root & 1.13 & 0.90 & 0.92 & 0.96 \\
\hline & & Shoot & 1.08 & 0.99 & 0.82 & 1.18 \\
\hline \multirow{8}{*}{$\begin{array}{l}\text { Soil with Neem } \\
\text { treatment }\end{array}$} & \multirow[t]{2}{*}{$25 \%$} & Root & 1.31 & 1.78 & 1.01 & 1.02 \\
\hline & & Shoot & 1.47 & 1.39 & 1.05 & 1.29 \\
\hline & \multirow[t]{2}{*}{$50 \%$} & Root & 1.41 & 1.08 & 0.88 & 0.92 \\
\hline & & Shoot & 1.38 & 1.37 & 0.88 & 1.14 \\
\hline & \multirow[t]{2}{*}{$75 \%$} & Root & 1.07 & 0.87 & 0.87 & 0.91 \\
\hline & & Shoot & 1.26 & 1.06 & 0.87 & 1.15 \\
\hline & \multirow[t]{2}{*}{$100 \%$} & Root & 1.07 & 0.79 & 0.88 & 0.88 \\
\hline & & Shoot & 1.14 & 1.02 & $\begin{array}{l}0.84 \\
\end{array}$ & 1.02 \\
\hline
\end{tabular}

The highest effluent tolerance index values are recorded at 25 percent of effluent concentration and the effluent tolerance index generally decreased for root and shoot with increase in the effluent concentration. The fresh weight (Gram/Plant) of Abelmoschus esculentus is shown in table-7.

Table 7: Fresh weight (Gram/Plant) of Abelmoschus esculentus grown under different concentrations of effluent with different soil treatments. $(n=3$. Mean $\pm S D)$.

\begin{tabular}{|c|c|c|c|c|c|}
\hline \multirow{2}{*}{ Soil Treatments } & \multirow{2}{*}{$\begin{array}{c}\text { Effluents } \\
\text { concentration }\end{array}$} & \multicolumn{4}{|c|}{ Age of the plants (days after sowing) } \\
\hline & & 15 & 30 & 45 & 60 \\
\hline \multirow{5}{*}{$\begin{array}{l}\text { Soil without } \\
\text { treatment }\end{array}$} & $0 \%$ & $0.298 \pm 0.092$ & $0.289 \pm 0.153$ & $0.771 \pm 0.313$ & $1.093 \pm 0.204$ \\
\hline & $25 \%$ & $0.522 \pm 0.089$ & $0.802 \pm 0.069$ & $1.121 \pm 0.991$ & $1.715 \pm 0.256$ \\
\hline & $50 \%$ & $0.524 \pm 0.158$ & $0.627 \pm 0.209$ & $0.938 \pm 0.046$ & $1.178 \pm 0.153$ \\
\hline & $75 \%$ & $0.537 \pm 0.117$ & $0.627 \pm 0.209$ & $0.794 \pm 0.150$ & $1.449 \pm 0.413$ \\
\hline & $100 \%$ & $0.478 \pm 0.248$ & $0.549 \pm 0.206$ & $0.948 \pm 0.143$ & $1.717 \pm 0.095$ \\
\hline \multirow{5}{*}{$\begin{array}{l}\text { Soil with Cow } \\
\text { dung treatment }\end{array}$} & $0 \%$ & $0.319 \pm 0.171$ & $0.371 \pm 0.145$ & $0.914 \pm 0.018$ & $1.313 \pm 0.100$ \\
\hline & $25 \%$ & $0.499 \pm 0.077$ & $0.775 \pm 0.046$ & $1.402 \pm 0.511$ & $2.216 \pm 0.262$ \\
\hline & $50 \%$ & $0.562 \pm 0.043$ & $0.775 \pm 0.138$ & $1.133 \pm 0.248$ & $1.778 \pm 0.735$ \\
\hline & $75 \%$ & $0.550 \pm 0.122$ & $0.696 \pm 0.084$ & $1.031 \pm 0.162$ & $1.829 \pm 0.313$ \\
\hline & $100 \%$ & $0.580 \pm 0.072$ & $0.618 \pm 0.103$ & $1.004 \pm 0.170$ & $2.075 \pm 0.544$ \\
\hline \multirow{5}{*}{$\begin{array}{l}\text { Soil with Neem } \\
\text { Treatment }\end{array}$} & $0 \%$ & $0.364 \pm 0.116$ & $0.356 \pm 0.112$ & $0.803 \pm 0.250$ & $1.990 \pm 0.278$ \\
\hline & $25 \%$ & $0.627 \pm 0.025$ & $0.934 \pm 0.030$ & $1.182 \pm 0.149$ & $2.004 \pm 0.224$ \\
\hline & $50 \%$ & $0.605 \pm 0.091$ & $0.874 \pm 0.035$ & $1.028 \pm 0.046$ & $1.540 \pm 0.279$ \\
\hline & $75 \%$ & $0.564 \pm 0.236$ & $0.648 \pm 0.142$ & $0.944 \pm 0.068$ & $1.802 \pm 0.157$ \\
\hline & $100 \%$ & $0.445 \pm 0.048$ & $0.549 \pm 0.206$ & $0.932 \pm 0.188$ & $1.621 \pm 0.252$ \\
\hline
\end{tabular}

\section{Volume 4 Issue 12, December 2015}




\section{International Journal of Science and Research (IJSR) \\ ISSN (Online): 2319-7064 \\ Index Copernicus Value (2013): 6.14 | Impact Factor (2014): 5.611}

The highest fresh weight was recorded at 75 percent effluent concentration for 15 days duration and at 25 percent effluent concentration for 30 and 45 and 60 days in soil set without treatment. In soil set with cow dung treatment the highest weight was recorded at 100 percent effluent concentration for 15 days but the fresh weight for $30,45,60$ days was recorded highest with 25 percent of the effluent concentration. The highest fresh weight in soil set with cow dung treatment was recorded at 100 percent effluent concentration for 15 days and the highest value of fresh weight was recorded at 25 percent of effluent concentration for 30, 45 and 60 days. The best results for the fresh weight soil set with Neem treatment were recorded at 25 percent for all days. The dry weight (Gram/Plant) of Abelmoschus esculentus is shown in table-8.

Table 8: Dry Weight (Gram/plant) of Abelmoschus esculentus grown under different concentrations of effluent with different soil treatments. $(n=3$. Mean \pm SD).

\begin{tabular}{|c|c|c|c|c|c|}
\hline \multirow{2}{*}{ Soil treatments } & \multirow{2}{*}{ Effluents concentration } & \multicolumn{4}{|c|}{ Age of the plants (days after sowing) } \\
\hline & & 15 & 30 & 45 & 60 \\
\hline \multirow{5}{*}{$\begin{array}{l}\text { Soil without } \\
\text { treatment }\end{array}$} & $0 \%$ & $0.085 \pm 0.031$ & $0.130 \pm 0.071$ & $0.187 \pm 0.050$ & $0.329 \pm 0.089$ \\
\hline & $25 \%$ & $0.154 \pm 0.053$ & $0.351 \pm 0.056$ & $0.336 \pm 0.103$ & $0.412 \pm 0.092$ \\
\hline & $50 \%$ & $0.137 \pm 0.027$ & $0.311 \pm 0.027$ & $0.305 \pm 0.006$ & $0.339 \pm 0.062$ \\
\hline & $75 \%$ & $0.144 \pm 0.020$ & $0.309 \pm 0.123$ & $0.233 \pm 0.123$ & $0.310 \pm 0.013$ \\
\hline & $100 \%$ & $0.145 \pm 0.053$ & $0.244 \pm 0.100$ & $0.305 \pm 0.092$ & $0.297 \pm 0.016$ \\
\hline \multirow{5}{*}{$\begin{array}{l}\text { Soil with cow } \\
\text { dung treatment }\end{array}$} & $0 \%$ & $0.093 \pm 0.050$ & $0.181 \pm 0.070$ & $0.286 \pm 0.047$ & $0.255 \pm 0.050$ \\
\hline & $25 \%$ & $0.168 \pm 0.025$ & $0.372 \pm 0.054$ & $0.283 \pm 0.039$ & $0.538 \pm 0.129$ \\
\hline & $50 \%$ & $0.164 \pm 0.020$ & $0.339 \pm 0.061$ & $0.294 \pm 0.021$ & $0.401 \pm 0.127$ \\
\hline & $75 \%$ & $0.157 \pm 0.030$ & $0.341 \pm 0.062$ & $0.261 \pm 0.142$ & $0.383 \pm 0.136$ \\
\hline & $100 \%$ & $0.148 \pm 0.021$ & $0.252 \pm 0.052$ & $0.294 \pm 0.086$ & $0.462 \pm 0.137$ \\
\hline \multirow{5}{*}{$\begin{array}{l}\text { Soil with Neem } \\
\text { Treatment }\end{array}$} & $0 \%$ & $0.138 \pm 0.073$ & $0.141 \pm 0.061$ & $0.202 \pm 0.010$ & $0.380 \pm 0.115$ \\
\hline & $25 \%$ & $0.139 \pm 0.016$ & $0.551 \pm 0.079$ & $0.344 \pm 0.057$ & $0.440 \pm 0.124$ \\
\hline & $50 \%$ & $0.168 \pm 0.012$ & $0.401 \pm 0.009$ & $0.259 \pm 0.055$ & $0.292 \pm 0.027$ \\
\hline & $75 \%$ & $0.192 \pm 0.081$ & $0.273 \pm 0.053$ & $0.228 \pm 0.055$ & $0.361 \pm 0.058$ \\
\hline & $100 \%$ & $0.125 \pm 0.020$ & $0.269 \pm 0.147$ & $0.311 \pm 0.100$ & $0.398 \pm 0.014$ \\
\hline
\end{tabular}

The highest dry weight in soil set without treatment was recorded at 25 percent of effluent concentration for all days and in soil set with cow dung treatment the highest value was also recorded at 25 percent of effluent concentration except for 45 days which was found highest for 50 percent of effluent concentration. The highest dry weight in soil set with Neem treatment was recorded at 25 percent of effluent concentration for 30, 45 and 60 days and the highest value was recorded at 75 percent of effluent concentration for 15 days.

\section{Conclusion}

The present study shows that the mixed effluent which was collected from Okhla industrial area phase-II has considerable amount of pollutants which comes from various plastic-moulding, textile, dye, printing press, electroplating, paper, chemical industries etc. The study shows that the effluent has an adverse effect on seed germination and plant growth of the Abelmoschus esculentus at the higher concentrations of effluents. But low concentration of effluent is less toxic and found suitable for seed germination and growth. The study suggests that the appropriate dilution of the effluent can be made to reduce harmful effects at the time of germination and growth of the Abelmoschus esculentus.

\section{Acknowledgement}

Three of the authors namely Sajid Ali, Firoz Ali Ansari and Tabassum Akhtar sincerely acknowledge the financial support provided by University Grants Commission, India.

\section{References}

[1] Al-Ansari, Nadhir., Aldardor, Wafa., Siergieiev, Dmytro. and Knutsson. (2013). Effect of treated wastewater irrigation on vegetables. Journal of Environmental Hydrology, 21, 5.

[2] Arora, M., Kiran, B., Shweta, R., Rani, A., Kaur, B., and Mittal, N. (2008). Heavy metal accumulation in vegetables irrigated with water from different sources. Food Chemistry, 111, 811-815.

[3] APHA. (1992). Standard Methods for the Examination of water and wastewater. $19^{\text {th }}$ ed. Washington D.C., U.S.A.

[4] Begum, Ara, Shameem., Alam, Jahangir.M., Rahman, Shyafur, Syed and Rahman, Mizanur. M. (2010). Effect of industrial effluents on the germination and seedling growth of three leafy vegetables. Bangladesh J. Sci. Ind. Res., 45(2), 101-104.

[5] Bhale, U.N. (2011). Tolerance of polluted water on seedling growth of some cereal crops. Int. J Latest Trends Bot. Sci., 1(1), 5-7.

[6] http://www.distancesfrom.in/delhi/okhla-industrialarea-phase-ii-latitude-longitude/627245.html. 


\section{International Journal of Science and Research (IJSR) \\ ISSN (Online): 2319-7064}

Index Copernicus Value (2013): 6.14 | Impact Factor (2014): 5.611

[7] Kumar, Vinod and Chopra, A.K. (2012). Effects of paper mill effluents irrigation on agronomical characteristics of Vigna radiate (L.) in two different seasons. Communications in Soil Science and Plant Analysis, 43: 2142-2166.

[8] Malik, A. Saeed., Bokhari, T.Z., Dasti, A.A. and Abidi Zaib-Un-Nisa.S. (2003). Effect of waste effluents from a tannery on the growth of some crop plants. Asian Journal of Plant Sciences, 2(8): 623626.

[9] Medhi, U.J., Talukdar, A.K and Deka, S. (2008). Effect of pulp and paper mill effluent on seed germination and seedling growth of mustard ( Brassica campastris), Pea ( Pisum sativum) and rice ( Oryza sativa) seeds. Pollution Research, 27(3): 437442.

[10] Nawaz, Sofia, Ali, Maria, Syeda. and Yasmin, Azra. (2006). Effect of Industrial Effluents on Seed germination and Early Growth of cicer arientum. Journal Biological Sciences, 6 (1): 49-54.

[11]Rao, G. M. and Kumar, N.V. (1983). Impact of tannery effluents on seed germination in Cicer arientum. Poll. Res.J., 2:33.

[12] Turner, R.C. and Marshal, C. (1972). Accumulation of zink by subcellulr fraction of some root Agrotics teneys in relation to zink tolerance. New Phyton., 71, 671-676.

[13] Uaboi-Egbenni, P.O., Okolie, P.N., Adejuyitan, O.E., Sobande, A.O. and Akinyemi, O.

a. (2009). Effect of industrial effluents on the growth and anatomical structures of Abelmoschus esculentus (okra). African Journal of Biotechnology, 8(14), 3251-3260.

[14] Vijayakumari, K and Kumudha, P. (1990) Effect of distillery effluent on seed germination and early seedling growth in some crop plant. Geobios., 17: 206-211.

[15] Vijayarengan, P and Lakshmanachary. (1993). Effect of textile mill effluent on growth and development of green gram seedlings. Ad. Plant. Sci., 6: 359-365.

[16] Wins, Albino. J and Murugan. M. (2010), Effect of textile mill effluents on growth and germination of black gram. International Journal of Pharma and Bio Sciences, 1 (1).1-7. 